\title{
AVALIAÇÃO DA QUALIDADE DA SILAGEM DE AZEVÉM (Lolium multiflorum Lam) ADICIONADA DE CASCA DE SOJA
}

\section{J.A.G. HILL ${ }^{1}$; P.G.C. LIMA ${ }^{2}$}

${ }^{1}$ Mestrando do Curso de Pós-Graduação em ciências Veterinárias, de Produção Animal da Universidade Federal do Paraná. Consultor em Nutrição Animal de propriedades produtoras de leite. ${ }^{2}$ Sócio Proprietário da Centaurus- Consultoria Veterinária - Conveniada à Cooperativa de Laticínios Curitiba Ltda. - CLAC.

Um dos grandes entraves para a produção de silagem de pastos verdes é o teor de matéria seca do pasto (material a ser ensilado), que, em geral, fica abaixo de $20 \%$. O presente trabalho tem por objetivo testar a qualidade da silagem de azevém sem nenhum tratamento, ou com diferentes tratamentos: pré-secagem por 6 horas, adição de $10 \%$ do peso de casquinha de soja, adição de $15 \%$ de casquinha de soja, adição de $20 \%$ de casquinha de soja. O trabalho mostra que na présecagem por 6 horas e na adição de $20 \%$ de casquinha de soja, o teor de matéria seca do ensilado é praticamente o mesmo. Neste trabalho também são mensurados os níveis de ácido butírico e ácido láctico dos diversos tratamentos e com estes dados faz-se discussão sobre o uso ou não, da pré-secagem de pastagens verdes com matéria seca inferior a $20 \%$. O azevém foi ensilado em tubos de cimento amianto com $40 \mathrm{~cm}$ de diâmetro e 1 metro de comprimento; foram utilizados 6 tubos para cada tratamento, isto é, 30 tubos. O azevém foi plantado numa propriedade produtora de leite na região metropolitana de Curitiba/PR. Após 45 dias de armazenagem nestes tubos, foram colhidas amostras compostas de cada um. Este material foi levado ao Laboratório de Nutrição da Universidade Federal do Paraná onde imediatamente se fez a mistura com ácido sulfúrico a $0,6 \mathrm{~N}$. Então o material foi deixado em geladeira por 8 dias, e após filtrado e congelado, foi levado, para Coronel Pacheco - MG (EMBRAPA - Centro de Gado de Leite) para análise dos ácidos graxos voláteis por cromatografia em fase gasosa.

Palavras-Chave: Azevém, Lolium multiflorum, silagem, casquinha de soja, gramíneas. 